\title{
From Theory to Praxis: Film Theories Translated
}

\author{
ANWITA MAITI \& \\ UDAYA NARAYANA SINGH
}

\begin{abstract}
\end{abstract}
The paper will explore the products and processes in intersemiotic transfers to start with. These instances in 'Transculturation' become interesting as they give rise to further theoretical debates. For example, one could raise another question as to whether the 'Feminist Film Theories' of the West could be applicable in the context of a different culture where textual translations happen from the verbal to the visual forms. For instance, one could test if the propositions espoused by the likes of Laura Mulvey (1975), Teresa de Lauretis (1987), and Kaja Silverman (1988) as under a feminist approach would be applicable while studying the trajectory of Indian movies. Intercultural translations being perhaps most prevalent and readily evident in the commercial films today, have numerous examples in Bollywood movies, art-house parallel movies, and the lowbudget new Indian movies. The other category presents a blend of the two polarities, borrowing features of commercial and art-house films, yet, not strictly confined to either. The only thing common among them is making a text fit into another cultural context or any other culture. The facilitation of viewing a film text in any or many languages (on multiple platforms) has thrown up a new kind of challenge to those engaged in the intersemiotic transfer. We argue here that a discourse on intersemiotic translation has much to draw from feminist film theories. Translating a critical approach that originates in one culture and to let it gain entry into another culture is a challenge in praxis. In the process, we offer a few observations on how the degrading standards of commercial 
Anwita Maiti \& Udaya Narayana Singh

Indian movies could change if we can implement some universally acceptable positions on gender equity.

Keywords: Intersemiotic Translation, Feminist Film Theory, Gender Equity, Transculturation.

\section{Introduction}

How disciplinary boundaries overlap and criss-cross is challenging to keep track of today. The purists and pundits engaged with translation as a process and product are stuck with ideas that created this inquiry field, whereas the broader field of Translation has taken a different course. In a recent essay titled 'Intersemiotic Translation as Resemiotisation: A Multimodal Perspective,' O'Halloran, Tan, and Wignell (2016: 119) made a fascinating comment about a niche area of translation today - 'Intersemiotic Translation' which is the focus of this paper. They write: “Today, Jakobson's (1959) definition of intersemiotic translation has been broadened to include translations across non-linguistic semiotic resources (e.g., Kourdis \& Yoka, 2014). This development seems inevitable, given the proliferation of different forms of multimodal texts in today's digital environment, where semiotic resources (e.g., language, image and sound resources) "coexist, cooperate, and get translated" (Kourdis 2015: 311) on a regular basis." Both for students of film studies and intersemiotic translation, it is increasingly clear that the way contents and expressions get remodelled in the verbal to visual transfer, there is a lot to learn from these texts.

It is an undeniable fact that films are a popular source of entertainment in India because they "speak" to us in our language. In a vast country with a significant degree of illiteracy, visual texts fill the space of verbal and printed books available in other cultures. With the far-reaching and extensive scope of cinema, people do get affected by what they see on screen and the kind of expressions they hear. The speech forms 
as well as the deviations from the standards become a norm for the impressionable. What spreads as a trend is not just the frozen expressions, semi-sentences or the syntax, but also the semantics. One generally tries to understand, after seeing a film, what exactly has been objectified or depicted. The visual texts do better commercially if a woman has been a matter of 'objectification.' The 'woman question' and objectification in novels have been a matter of debate in the 1970s when the gender treatment had not been balanced. The matter gets aggravated in the visual texts. If they are positive depictions, we find the protagonists or characters respected for their quality of mind and individualities. There had been negative depiction of women even in the western world and in the cinema emanating from there even though there had been many attempts to raise awareness. The discussions on gender issues world-wide, however, have not had much impact on Indian film-making. Whereas the anti-obscenity movements that gained momentum in 1970s against certain printed and published texts resulted in a general restraint later. While transferring texts into films, the distortions have surfaced again and again. Thus, the verbal and visual texts in the same sociocultural contexts speak in different languages.

In this paper on 'Transculturation', we look into the ideas about gender imbalance as in the works of some critical feminist theoreticians to explore if the inevitable cultural clashes that happen when a target and a source culture confront each other give rise to a 'neoculturation' in the sense of Fernando Ortiz (1940/1995). There are two levels at which transculturation is in operation here. Ideally, a change in the 'outlook' and 'approach' should bring in a change in the mindset of authors of verbal and visual texts in a post-colonial set up that has received both technologies of transfer as well as methodologies of 'viewing' the 'Other'. However, the intersemiotic transfers in these cultural spaces do not reflect 
the phenomenon of merging and converging cultures fully. Transculturation in the Indian space shows a transition from one kind of culture to another by acquiring only some traits of another culture by way of acculturation, while showing uprooting of an existing cultural tradition by way of partial deculturation. When films and visual texts from another culture have invaded our 'reading' or 'viewing' spaces (thanks to sub-titling and dubbing as well as plurilingual versions) unlike the earlier situation where one had to wait for a verbal text to be textually translated by a bilingual translator, one would expect a cultural hegemony through these processes. However, what has happened in the instances of intersemiotic transfers in making of Indian cinema has been very different.

In this context, a few important developments have been noticeable. The first among these is the rise of critical feminist film study in the works of the western theoreticians such as Laura Mulvey (1975), Teresa de Lauretis (1987), and Kaja Silverman (1988). The second aspect has to do with the methodology that could be adopted to study films as translations of texts through a feminist angle. The third possible viewpoint could be as to how the feminist film theories could be translated or brought into praxis in studying Indian movies. The emergence of Parallel Cinemas in India and how they attempted to transform our society by representing women with respect and regard offers a fourth point to look into. The fifth point is that the new Indian films that have taken up women's cause very seriously raise a lot of hope that ultimately perhaps the feminist theories about gender equity are getting translated into practice, although not in the mainstream movies. In the concluding thread, we also discuss how a few positive steps vis-à-vis making women-centric movies could ensure that theories and movements towards gender equality could be translated into action in the Indian context. In brief, the paper focuses on 'Translation' in two 
ways: (i) It focuses on how translation of fiction into films get a kind of distortion that comes from a typical manipulation, and we are all aware of the stand 'Translation as Manipulation' (See Singh ); and (ii) how - metaphorically speaking, theory to practice 'Translation' or 'Transmigration' suffers in cultural/ textual creativity.

\section{Feminist Film Theories and Theorists of the West: Foregrounding the 'Woman' Question into Perspective and its Further Implementation}

\subsection{The Theories}

In the context of 'Feminist Film Theory' as it evolved in the 1960s with the advent of second-wave feminism and with the arrival of Simone De Beauvoir's The Second Sex (1949), Betty Friedan's The Feminine Mystique (1963), and Kate Millet's Sexual Politics (1970), many changes were observed in all kinds of cultural productions. These had had a serious impact on both approaches to fiction and films. We see new products and positions emerging from both 'American Sociological and Historical Theory' and the 'British Critical Theory.' Whereas many studies under the former analyse the role played by women in different narratives and genres and the screen time and space given to them, the latter problematized this issue in critiquing fictions and films. In that context, Marjorie Rosen's book Popcorn Venus: Women, Movies, and the American Dream (1973) talked about how many movies depict women as oppressed beings and also glorified this pattern of depiction. Similarly, in From Reverence to Rape: The Treatment of Women in Movies (1974), Molly Haskell studied if the representation of women in Hollywood during the '70s was realistic portrayals. Claire Johnston's essay Women's Cinema as Counter Cinema (1973) opined that films did not reflect women's reality at all. Instead, they gave rise to myths 
constructed by a patriarchal society, structured for gratifying male desires. She remarked:

As the cinema developed, the stereotyping of a man was increasingly interpreted as contravening the realization of the notion of 'character'; in the case of a woman, this was not the case; the dominant ideology presented her as eternal and unchanging, except for modifications in terms of fashion, etc. (Johnston 1973: 2).

Film theorists in England like Claire Johnston, Laura Mulvey, Pam Cook and Annette Kuhn drew perspectives from psychoanalysis, poststructuralism, semiotics and Marxism. Critical Theory was later referred to and absorbed into the American sphere as well. In her Notes on Women's Cinema, Claire Johnston (1973) focused on the tenet of iconography in cinema, examining how women were framed, glorified, and attired in movies solely to cater to male desires. In the fictions of 1960s and 1970s, such descriptions of women occupied some space in the verbal texts, too. However, the effect of a visual text was more impactful in comparison to their literary counter-parts.

Feminist film theory highlighted the following aspects: 'representation,' 'production,' 'spectatorship,' 'psyche' and 'body' where the methodology of representation questions how the director as auteur had placed women on the screen, the ratio of screen space given to men as compared to women, and whether the portrayals were realistic reflections of society. 'Representation' thus pointed out the sexism involved where patriarchal mentalities showed up women in an inferior light. Women were depicted as easily tameable alluring objects whose attitudes could be moulded according to the wishes of men. The concern with 'Production' reflected on how Feminist counter cinemas could be made more in number and could become more expansive. How such parallel texts reached out 
to viewers through the 'Feminist Film Festivals' held in the US, Britain, and Canada in the early 1970s was a case I point in this regard. 'Spectatorship' focused on 'audience reception' and wanted to know the ideas viewers formed about the women characters when they watched movies. The concept of 'Psyche' was based on psychoanalytic theory, especially those propounded by Jacques Lacan and Sigmund Freud, where feminist film theorists sought to understand the role cinema played in constructing a viewer's sense of 'self,' about how they engaged with their sexual identities. As for their view on the last point, the feminist filmmakers discuss the 'Body', focusing on the indispensable connection between mind and body where the sense of touch is not just limited spatially to the screen, but it evokes an array of feelings and emotions in the viewers' minds as well.

In the 1980s, some film theoreticians extended this scope by focusing on 'class,' 'queer theory,' 'postcolonial theory' and 'critical race theory.' Feminist film theory then took a turn toward Cultural Studies in the 1990s where the realization dawned that sociological and psychological analyses weren't enough, but also the response and reception of the audience were essential. It was equally important to critically view the film texts in comparison with their source products, literary texts. The 'audience reception' was already included in pedagogy. Yet, it followed a two-pronged approach: (i) textoriented study- focusing on the film's narrative, and (ii) audience studies and reception theory- focusing on the polysemy aspect of the movies.

\subsection{The Theorists}

Elisabeth Lenk, a German sociologist spoke out on how women have to "bear the brunt of the ideal beauty" (Ramanathan 2006:11) and the Art Historian David Summers pointed out the extent to which aesthetics is controlled mostly 
by men, and women simply function as figures to be fetishized and obsessed about, by remarking, how,

...our understanding of women and our understanding of art are in dialectical relation to one another that our idea of art positively excludes the idea of women at the same time that it is absolutely dependent upon the idea of women for its definition (Summers 1993: 253).

As a movie maker, Jonathan Schroeder noted, "Film has been called an instrument of the male gaze, producing representations of women, the good life, and sexual fantasy from a male point of view" (Schroeder 1998: 208), he stated how the gazer is considered as superior, and the gazed as inferior. In the book Imaginary Signifier (1982), in the chapter "The Passion for Perceiving" Cristian Metz said, "The practice of cinema is only possible through the perceptual passions: the desire to see (= scopic drive, scopophilia, voyeurism), which was alone engaged in the art of silent films..." (Metz 1982: 58).

Laura Mulvey, Teresa de Lauretis, and Kaja Silverman have pointed out this fact of representation of women in a subservient light. Mulvey and Silverman's work on Hollywood movies and Laurentius' on Hollywood and Italian movies have all resulted in the overall conclusion that women are indeed much underrepresented and are mainly projected as objects of male desires, and not as their subjects. The 'Male Gaze' remains a contentious topic in film studies. In her essay, Visual Pleasure and Narrative Cinema (1975), Mulvey borrowed Freud's psychoanalysis to explain how men watch movies to gaze at female bodies and gratify their sexual desires, or what is otherwise called 'Scopophilia.' She drew examples from classic Hollywood movies of the 1950s and 1960s which exposed women to men as objects to be looked at to derive satisfaction. She listed the two instances of the male gaze that 
underplay: the first being voyeuristic where the woman is only an image for viewing at, and the second is fetishistic where men gratify their sexual desires by gazing at women. Mulvey mentioned how "The cinema offers several possible pleasures. One is scopophilia" (Mulvey 1975: 10). She commented:

The magic of Hollywood style at its best (and of all the cinema which fell within its sphere of influence) arose, not exclusively, but in one crucial aspect, from its skilled and satisfying manipulation of visual pleasure. Unchallenged mainstream film coded the erotic into the language of the dominant patriarchal order (Mulvey 1975: 9).

She underlined how women are the image and men are the bearer of the look and also brought to notice the fact that women are always bogged down with the task of being available objects of desire that hold "appearance coded for strong visual and erotic impact” (Mulvey 1975: 10).

In her book The Technology of Gender (1987), Teresa de Lauretis pointed hegemony of the male gender over the female and how this notion has been incorporated in films as well, by drawing on Foucault's opinion on how the male gender is always inevitably seen in a higher position in hierarchy almost everywhere in societies and hence the assumption is automatically induced into media as well. De Lauretis reflected:

Gender has the function (which defines it) of constituting concrete individuals as men and women. That shift is precisely where the reflection of gender to ideology can be seen, and seen to be an effect of the ideology of gender. The shift from "subjects" to "men and women" marks the conceptual distance between two orders of discourse, the discourse of philosophy or political theory and the discourse of "reality" (Lauretis 1987: 6). 
Kaja Silverman, in her book The Acoustic Mirror (1988), brings to notice how women's voices and speeches are "unreliable, thwarted, or acquiescent" (Chaudhari 2009: 45). Often, we see women speaking in a submissive manner in a low or a feeble voice in comparison to men. Their views do not seem self-assured. The movies glorify scenes where women are crying, panting, or screaming, but rarely do they allow women to talk boldly.

\section{Analysis: A Methodology for a Feminist Study of Films}

What we observe is how the feminist film theorists have sternly expressed their disappointment with how the filmmakers depict women in a demeaning manner. They made it clear that one should analyse and establish if women's representation in the movies is positive or negative. Because people are prone to get hugely influenced and affected by what they see on screen, they should in no way form belittled ideas and notions about women in their minds. To take up women's causes is to consider human values and hence, the aforementioned Western Film Theories and Film Theorists' works have been discussed, in order to approach at study of the making of women-centric movies, and for that, the following points, which on being inferred from the postulations of the film theorists, could prove with compelling feminist insights, while researching any movie, and these are:

\section{a. Screen' Space and Time' allotted to Women} Characters- whether movies for the majority period centre around men, with women sidelined and are presented sporadically for entertainment or are the women characters equally valued as the men characters, where they both have equal rights to share the screen.

b. Representation of Women on Screen- whether they exist as the only addendum in the story that circles around men or are presented as individual entities. 
c. Audience Reception- how people react to the way women are presented on screen. As cinema is an 'industry', it caters to the audience's wishes too, as their verdicts often affect the fortune of a movie. After all, all producers aim at money-making, where pleasing the consumer remains a critical criterion.

d. Inclusivity- a diversion from 'heteronormativity' to be more gender fluid, where the idea is to be nonconforming, non-binary, and to be inclusive of the third gender people. Forced heteronormativity imposes assertion of men over women and exalts 'Phallocentrism,' where the focus is about appeasing the male audience.

\section{The Issue of Lack of Reality in Indian Movies and Translation of Texts into Visual Narrative that has Socio- Cultural Repercussions}

A common criticism against the mainstream movies is that they do not show the real world. These films often deviate from the truth and project a fantasy world to the audience. They also carefully select dance sequences and songs to present actresses in skimpy clothes to show their bodies. In short, these movies engulf the viewer's mind by entertaining the person's visual and hearing senses, by situating women in a detrimental context.

If we need to test reality and pragmatism, we need to put the very own, popular Bollywood movies to the litmus test. By the term of Bollywood movies, we refer to the commercial Hindi language films made in Mumbai. Bollywood has been an extremely profitable industry in India, producing around eight hundred films every year. The audiences are not only Indians, but they also include viewers from South Asia, the Middle East, and East Europe. It becomes essential to study the representation of women in Bollywood movies, as they are 
much responsible for the translated image they have outlined in the world about Indian women. A majority of the Bollywood films are not only unreal, but also abnormally shrewd in distorting the representation of women characters to make them look only as objects that exist solely for appeasing the senses of the male audience. Bollywood movies are very prone to represent women as dutiful daughters, lovers, wives, mothers, aunts, and grandmothers. Since women are often held as the repositories of culture and tradition, the burden of agelong patriarchal and misogynistic practices weigh on them, and movies glorify that. The idea of a modern woman comes only with the change in her attire, especially when she is in western clothes. But the moviemakers project a 'fixed' mentality of the women protagonists to give the message that they are the same women just like their mothers and grandmothers were, which is, they submit before male dominance, gleefully.

It is the responsibility of movie directors to make meaningful movies because the masses lack clear judgment or conscience and is willing to gulp thoughtlessly any available film, which they can watch easily for sheer entertainment. As long as the movies are visually captivating and colourful, and exhibit the tensions in the appealing storyline, they will watch anything that comes in movie theatres or on the internet. The audience will take these shallow movies seriously, and the most severe lesson they will learn is that women are just objects, and men should always control women. Indian filmmakers are not cautious about the negative influences their movies give out to society and its people. Instead, they have turned cinema into an industry and have also brought down the standards of storytelling. Thus, they have done injustice to the original idea that films can also be beautiful and meaningful, and an organ of socio-cultural change. That cinema's visual translation can influence people positively, and act as social reform is forgotten now. 
In their work on Culture Industry, Adorno and Horkheimer (1944) projected their disapproval and concern about how films being a part of culture were bringing upon ruination in society. While the scholars were trying to bring to focus the extent of harm films were doing to the community, moviemakers, on the other hand, were reaping benefits because they knew that a majority of the common masses could not reason or argue. This trend continued from 1950s to 1990s when the authors or film-makers did not have to face a barrage of social media outburst as audience-reactions. As long as readers and audiences were captive in some ways, this cultural ruination continued. In the context of Bengali literature, the debasement that was brought in by a group of fiction writers led by Samaresh Basu proved this point. The debasement in Bengali poetry during this period was pointed out very aptly by Singh (2010) in a longish piece. These film-makers knew that despite formal education, the large group of movie watchers was ignorant and would not aim at refining themselves or their taste.

\section{Parallel Cinemas in India and Attempts to Transculturation}

In the Indian sphere, the Parallel Cinema Movement from the 1970 s to the 1980 s that made pragmatic movies had given a voice to women. Produced in different languages across different states of India, the movies differed from the typical commercial movies made in Bollywood where male-centrism was an overriding tenet. Many of these new breed of filmmakers sincerely believed in the validity of the critical feminist theories and how they should be implemented in our cultural contexts. Deriving inspiration from the avant-garde films, which paved the way for changes in the American film industry, and signalled the rise of Italian 'Neo-Realist Cinema', their choice of literary texts to render into films and 
depiction of characters on celluloid deviated much from the mainstream commercial films. This move sent across a powerful message to the masses.

With a focusing on depicting women's issues, they meet the criteria of allotting screen 'space and time' to women characters, and represented women on screen in a positive and empowered light. For them, voicing women's concern was of seminal importance. They did show concern over what gets read and what is viewed by the audience, because for them, social and cultural harmony was important. In some ways, social reform was also their concern, rather than achieving monetary success. The commercial world, film producers, as well as publishers of fiction both would still want to see malefavouritism reflected in their products. Lastly, the parallel movies also deviated from assumed heteronormativity where power relations often came into play with the need to assert men's control over women.

In promoting powerful and parallel cinema, the NFDC (National Film Development Corporation) had a major role in being the chief funding agency for these low-cost idealistic moviemakers. It had helped around 300 productions in repertoire in both National ${ }^{1}$ and Regional ${ }^{2}$ spaces. Parallel moviemaking had a downturn in the 1980s where there was a slump in the production because of the scarcity of money with NFDC. Also as the colour television was introduced in 1982 and eventually film-making and television-productions began to be in sync, it made people get more attracted to colourful and entertaining media in the comfort of their home. The challenge intensified with the advent of the internet in India in 1995, whereby people wanted to see more of the western

\footnotetext{
${ }^{1}$ National Movies are primarily the Bollywood movies.

2 Regional Movies are the movies made across different states in India apart from the Bollywood industry.
} 
world, and even movies from the Asian film industries. Of course, the satellite television opened up more western movies and soaps, which enthralled and entertained Indians.

With the onset of parallel movie making and its influences, many influential films came into production that depicted women's place in the Indian society. These include Shyam Benegal's Ankur (1975), Nishant (1975) and Bhumika (1977) from the National sphere, Satyajit Ray's Aranyer Din Ratri (1970) from Bengal, Adoor Gopalkrishnan's Elippathayam (1982) from Kerala and Girish Kasaravalli's Ghatashraddha (1977) from Karnataka. Many of them also depicted the changes that were coming with the empowerment of women.

Not to feel deterred, Parallel movies had their resurgence in the early 2000s in Mumbai, where a group called 'Mumbai Noir,' began making real-life movies pivoting around urban life stories of ordinary people in Mumbai. Few examples of such filmmakers include Nagesh Kukunoor ${ }^{3}$, Manish Jha ${ }^{4}$, Kalpana Lajmi $^{5}$, Madhur Bhandarkar ${ }^{6}$, Sudhir Mishra, and Anant Balani. ${ }^{7}$ Raj Kumar Gupta's No One Killed Jessica (2011), Milan Luthira's Dirty Picture (2011), Nishta Jain's Gulaab Gang (2014), Aniruddha Roy Chowdhury's Pink (2016), Nitesh Tiwari's Dangal (2016), Vikas Bhal's Queen (2014), or Kahani (2012) made by Sujoy Ghosh, and Piku (2015) by Shoojit Sircar also fall into this type. In all such instances of intersemiotic transfers, the source texts were often a series of newspaper and media texts that allowed the film-makers to access a story.

\footnotetext{
3 Deewarein (2003), Dor (2006) and Lakshmi (2014)

${ }^{4}$ Matrubhoomi (2004)

${ }^{5}$ Rudaali (1993), Darmiyaan (1997), Daman (2001) and Chingaari (2006)

${ }^{6}$ Chandni Bar (2001), Satta (2003), Page 3 (2005), Corporate (2006), Fashion (2008) and Heroine (2012)

${ }^{7}$ Chameli (2003)
} 
Soon thereafter came the Indian moviemakers who transcended globally and made feminist and women-oriented movies. One could mention here Deepa Mehta's trilogy of Fire (1996), Earth (1998), and Water (2005) and Meera Nair's Monsoon Wedding (2001) and The Namesake (2006). There are several regional film directors, too - such as Aparna $\mathrm{Sen}^{8}$, Kaushik Ganguly ${ }^{9}$ are Rituparno Ghosh ${ }^{10}$ from Bengali film world, Aashiq $\mathrm{Abu}^{11}$ and Martin Prakkat ${ }^{12}$ from Kerala, Nag Ashwin ${ }^{13}$ from Andhra Pradesh, Nelson Dilipkumar ${ }^{14}$ from Tamil Nadu, Sameer Vidwan ${ }^{15}$ from Maharashtra and Bhaskar Hazarika ${ }^{16}$ from Assam whose choice of the literary source texts and their visual depiction changed the film audience tastes.

\section{Concluding Thread: Borrowing Translation to Reach at Possible Solutions}

An intersemiotic translator faces two challenges at the same time. One is in the choice of literary texts to base the film on depending on how realistic they were. The other is in the process of transculturaion, or in translating cultural theories in general, and feminist film theories in particular into practice while making a cultural product. They are to be aware that great literary texts are those that reverberate in the minds of their readers. It is often the case that they feel as if these texts were their own life-stories. How truly these texts could be taken into a resulting visual texts is the challenge. The need to

\footnotetext{
${ }^{8}$ Paromitar Ek Din (2000), Iti Mrinalini (2010) and Goynar Baksho (2013).

${ }^{9}$ Kaalbela (2009) and Shunyo Awonko (2013)

${ }^{10}$ Chokher Bali (2003)

${ }^{11} 22$ Female Kottayam (2012)

${ }^{12}$ Charlie (2015)

${ }^{13}$ Mahanati (2015)

${ }^{14}$ Kolavamu Kokila (2018)

${ }^{15}$ Anandi Gopal (2019)

${ }^{16}$ Kothanodi (2015)
} 
ensure that visual narratives of the cinematic text have a positive socio-cultural influence on viewers' mind, irrespective of their gender or class affiliations, is important. Today, when many in the other culture take up the case of equity and egalitarianism, so much so that there were interesting and empathetic depiction of the third gender and the cultural and political minorities in societies, there was no reason why the Indian authors of verbal and visual texts would remained caged in an outdated mode of cultural production.

Laura Mulvey urged for an alternative and didactic course to movie making that would allow building a story around women and situate women in her social context. The idea was to dismantle traditional movie making, which prioritized men and men's desires. She further advocated for the complete rejection of mainstream cinema and the sexist pleasure they offered by building on a fantasy. However, many feminists did not agree that it would be a feasible option since people were still hugely attracted to the popular commercial movies, film stars and big production banners. Because of the marketforces, a total dismantling of popular commercial films would neither be possible nor useful. There had to be a compromise because the audiences were, after all, the 'consumers' in the end. A mere polemical technique without the power of storytelling technique in movie-making would not receive their attention. It has been rightly observed by many scholars, such as Soumya Nandakumar (2011) that the mainstream commercial Hindi film upheld the traditional patriarchal views of society which was always fearful of female sexuality. In these films, we find glorification of the image of ideal Indian woman. They must accept injustice and violence meted out towards them by men-folk and social institutions. Thus, violence against women has always been one of the standard components of the Hindi commercial formula cinema (Dasgupta \& Hegde 1988). 
However, the rise of feminist media studies has paved the way for feminist film making and parallel cinema movement. We do see an increase in the number of feminist movie directors these days. Even though popular commercial movies are still the ones that keep entertaining audiences and generate a lot of revenue and profit, the important contribution of feminist movie directors cannot be denied. With the emergence of a large number of female fiction-writers, or writers with conscious attempts to foreground the cause and condition of women, these texts are also getting into film versions with great success. As Srijita Sarkar (2012) of the University of Loiseville argues, with the growth of number of womencentred movies in India, more and more spectators are becoming aware of the socio-cultural, economic, and political stances of women in society. In many societies, women still occupy a lower position in the social hierarchy in comparison to men. However, the trend of depiction of strong women protagonists acts as triggers to revolutionary changes bringing in a positive influence on the viewers.

In recent times in India, what is interesting to note is the gradual blending of the Art House or Parallel Cinema and Commercial Cinema since mid-2000. We note that this new set of films captivates more audiences. Along with imparting messages on social reform, they also have the capability of entertaining the audience through songs, dance, and choreography sequences. Many Art House movies appear to be strict and boring to most viewers as they fail when it comes to popular entertainment, and Commercial films are shallow and deceptive, as they mistreat women and underrepresent them.

By proposing unique ideas with reformist goals that challenge patriarchy and male-centrism, the feminist movie directors did find initially that their movies were unwelcome as they were humanistic in the way they liked to depict women. But as 
director and actor Aparna Sen opined, "Women's issues are to be part and parcel of humanism itself- something that I believe in and try my best to live by" (Kabir 2008: 3). The underrepresentation or misrepresentation of women in cinema makes it important to take up women's causes and give space to them in movies. Unlike mainstream commercial films that undermine women and send a wrong signal to the masses about how women should be treated, these film-makers have ensured that their cinema is not only entertainment, but must make the audience think about the reality and move away from an unreal world.

The changes in attitude will come only from cultural movements in societies. 'Make Meaningful Movies', or 'Triple-M' could be a joint effort made by the Movie Makers, including actors, directors, story-writers, and screenplaywrights as a gender-sensitive authors, just as any other popular move such as @MeToo. Since most production houses dealing with films and television products aim at earning huge profits, the move could serve as a social force to prompt them into thinking constructively about sending a message across society and people. On their part, the government of the day could invite them to take up joint projects, or fund proper act of intersemiotic transfers just as NFDC had once done - which is where the role of state-funded organizations could come across as a great impetus. The alternate, non-commercial movies made by students, faculty and newcomers should receive great support through a planned move. ${ }^{17}$ Conducting more International and Regional Film Festivals where the movies often deal with Women's Issues is another way to bring in change.

${ }^{17}$ The FTII (Film and Television Institute of India), Pune, and SRFTI (Satyajit Ray Film and Television Institute), Kolkata could take the lead in this direction with government patronage as part of their advocacy. 
There have been numerous instances of intersemiotic transfers in India in the recent times that paid adequate attention to the gender balance. The following translations into film that pay attention to women's issue is only a brief list:

a. 'Paar' (The Crossing) (1984), Director- Goutam Ghose --based on Samaresh Basu's short story 'Paari' (Journey)

b. 'Nagamandala' (Serpent Ritual) (1997), Director- T. S. Nagabharana --- based on Girish Karnad's 1988 play by the same name

c. 'Rudaali' (1993), Director- Kalpana Lajmi --- based on Mahasweta Devi's short story 'Rudali' (1993)

d. 'Bhalo Theko' (Take Care) (2003), Director --- Goutam Halder - based on Leena Gangopadhyay's story Janmadin (Birthday) (2003)

e. 'Goynar Baksho' (The Jewellery Box) (2013), DirectorAparna Sen --- based on Shirshendu Mukhopadhyay's short story 'Rashmonir Sonadana' (Rashmoni's Gold)

f. 'Aami Doghi' (The both of us) (2018), Director- Pratima Joshi - based on Gauri Deshpande's short story 'Paus Ala Motha'

g. 'Umrao Jaan Ada', perhaps the first Urdu novel by Mirza Hadi Ruswa, published in 1899, depicting the life and story of a courtesan and poet by the same name from $19^{\text {th }}$ century Lucknow, made into a film by Muzaffar Ali in 1981 . There were four films made on the same novel, showing the popularity of the text.

h. 'Parineeta', a 1914-Bangla novel by Sarat Chandra Chattopadhyay, made into seven different films in several Indian languages - a 2005-film in Hindi by Pradeep Sarkar, which had been a commercial success. But with the same name, it appeared as a film text in 1942 made by Pashupati Chatterjee, re-made by Bimal Roy in 1953 and by Alamgir Kabir in 1986. Parineeta in Bangla appeared in visual text 
directed by Ajay Kar in 1969, and in Tamil - Manamalai (1958) made by Narayana Rao.

If one adds Tagore's fictions such as 'Chokher Bali' (1903) or 'Ghare Baire' (1916) or 'Gora' (1910) and numerous short fictions such as 'Kshudhita Pashan' (1895) made by Tapan Sinha in 1960 or 'Nashtanir' (1901) - made into Charulata (1964) by Satyajit Ray, the list will seem endless. Similarly, there were also regional films that highlighted the social problems with patriarchy, as in 'Ara Nazhika Neram' (Half an Hour Only), Kerala Sahitya Academy award winning Malayalam novel by Parappurath in 1967, made into a powerful film by K. S. Sethumadhavan in 1970. The story focused on an orthodox Christian family from Travancore headed by Kunjenachan, an old patriarch in his 90s who lived his life in his own terms. Many other current social issues also came up through many other films such as 'Chemmeen' - a Malayalam novel by Thakazhi Sivasankara Pillai in 1956, made into a film, adapted into a screenplay by S. L. Puram Sadanandan and directed by Ramu Kariat in 1965. The film raises the issue of female sexuality and chastity and tells the story of the relationship between Karuthamma, the daughter of a Hindu fisherman, and Pareekutti, the son of a Muslim wholesaler of fishes in the coastal Kerala region. The depiction of the lives of fishermen by Thakazhi was captured with great emotional detail in the film.

It is clear that changes in the mindset about sourcing appropriate stories to translate into visual texts had also set in early on in the post-70s period. It is true that after the focus has shifted from a mere economic development to human development, gender parity in several areas could be seen. That included equal rights to vote or equal access to education, or right to parental property etc. However, one cannot anymore pretend not to know that in terms of a World Bank estimate - 
"in no region of the developing world are women equal to men in legal, social and economic rights" (World Bank 2001: 1). The issue is not if the translated visual texts paint an unreal universe, as many commercial film-makers re-emphasize that they drew their stories from the real life. However, as Nudrat Raza (2015: 74-75) argues: "Portrayals of men changed with time, adapting to the development discourses". However, women are still, with a few exceptions, portrayed through the nationalist project view. It can then be said that the contradiction between the portrayal of women, and the women's empowerment development discourse is, on a broader level, a contradiction between the development approach of women empowerment and Indian state's version of the 'ideal Indian woman'. Although many regional films are very positive, and address these issues well, but people from other parts of the country could hardly get to see them, as many of them had been rarely dubbed in other Indian languages. The discussion on these regional movies is therefore limited to their linguistic boundaries.

What we see is a definite turn towards gender equity as women's issues are taken up by many directors now, both male and female movie-makers. Even though popular and stereotypical films are those where women are still commodified, the new generation films are changing the perspective. As more women-centric films emerge, the viewers become more aware of women's issues.

In the Indian context, in order to make more women-centric movies, what are to be kept in mind are the aforementioned parameters of:

a. Changes in the screen space and time allotted to female characters.

b. Representation of women with voices and opinions on screen. 
c. Audience reception and turn against objectification and commodification, and

d. Inclusivity, to encourage representation of people from the third gender community, or LGBT community.

With the above, the negative representation of women in commercial Indian films could be curbed. But it is equally important for film-makers to look for appropriate literary texts that are well-received in society and are not gender-biased. These cannot be imposed from the top as the stricter censor rules in screening and filtering of media images could end up in protracted legal fight and politicisation of the issues. The themes such as women's liberation may not be to the taste of such official watchdogs. They might rather let go the media files that devalue women. The problem was with the small screen releases; as such debasements could enter into television screening and reach family viewing spaces. In this way, the cultural value-system will take a beating. Otherwise, filmmakers will keep making misogynistic art products as they know it will be the easiest way to capture the market. Some may appear to be progressive and egalitarian, but deep down they may still want to keep up with their idea that only men should rule the world. Hence, for women's emancipation to come to fruition, the effort should be made by the powers that would include the movie industry leaders and the alert masses. In that context, a greater number of successful intersemiotic translations would perhaps have a lasting impact.

\section{References}

ABHISAYS. 2012. List of 100 Best Bollywood Hindi Art Films. https://abhisays.com/movies/list-of-100-best-bollywoodhindi-art-films.html (Accessed17-09-2017).

Blaetz, RoBin. 2018. Avant-garde and Experimental Film. https://www.oxfordbibliographies.com/view/document/obo- 
Anwita Maiti \& Udaya Narayana Singh

9780199791286/obo-9780199791286-0082.xml (Accessed 26-06-2017).

BAudy, L. \& CoHEN, M. 2009. Film Theory and Criticism: Introductory Readings. USA: Oxford University Press.

Chakravarty, Sumita S. 1993. National Identity in Indian Popular Cinema, 1947-1987. Austin: University of Texas Press.

Chaudhuri, Shohini. 2006. Feminist Film Theorists: Laura Mulvey, Kaja Silverman, Teresa de Lauretis, Barbara Creed. Oxon: Routledge.

COOPER, DARIUS. 2000. The Cinema of Satyajit Ray: Between Tradition and Modernity. Cambridge: Cambridge University Press.

Cowie, ElizABeth. 1997. Representing the Woman: Cinema and Psychoanalysis. Minneapolis: University of Minnesota Press.

Dasgupta, S. D., \& R. S. Hegde. 1988. The Eternal Receptacle: A Study of Mistreatment of Women in Hindi Films. In R. Ghadially (ed.), Women in Indian Society: A Reader. 209- 216. New Delhi: Sage Publication.

De LAURETIS, TereSA. 1987. Technologies of Gender: Essays on Theory, Film, and Fiction. Bloomington: Indiana University Press.

FilmiBEAT. 2017. Aparna Sen Biography. https://www.filmibeat.com/celebs/aparnasen/biography.htm 1 (Accessed 5-01- 2017).

HAMmetT, JenNifer. 1997. The Ideological Impediment: Feminism and Film Theory. Cinema Journal, 36(2). 85-99. Hogan, PATRICK COLM. 2008. Understanding Indian Movies: Culture, Cognition, and Cinematic Imagination. Austin: University of Texas Press.

JoHN, T. 2010. The Golden Era of Indian Parallel/Art Cinema and its Decline. https://www.indiastudychannel.com/ 
resources/133935-The-Golden-Era-Of-Indian-Parallel-ArtCinema-And-Its-Decline.aspx (Accessed 17-09- 2017).

Johnston, Claire. 1973. Notes on Women's Cinema. London: Society for Education in Film and Television.

KabIR, NASREen MunNi (ed.). 2008. Women in Indian Film. New Delhi: Zuban Books.

Metz, CHRISTIAN. 1982. The Imaginary Signifier:

Psychoanalysis and the Cinema. Bloomington: Indiana University Press.

Mulvey, Laura. 1975. Visual Pleasure and Narrative Cinema. Screen, 16 (3). 6-18.

Mulvey, Laura. 2009. Visual and Other Pleasures. 2nd edn. Houndmills, Basingstoke, Hampshire England, New York: Palgrave Macmillan.

NANDAKUMAR, SOWMYA. 2011. The stereotypical Portrayal of Women in Commercial Indian Cinema. Department of Communications, University of Houston:USA. (M.A. Dissertation).

O’Halloran, Kay L., Sabine Tan \& Peter Wignell. 2016. Intersemiotic Translation as Resemiotisation: A Multimodal Perspective. Signata: Annales des Semiotiques 7. 119-229. Penley, Constance (ed.). 2013. Feminism and Film Theory. Routledge.

Ramanathan, Geetha. 2006. Feminist Auteurs: Reading Women's Films. London: Wallflower Press.

RAZA, NudRAT. (2015). Deconstructing Gender Roles in Bollywood Films: Through Women's Empowerment Development Discourse - Content Analysis of Popular Bollywood Films. Program of Global Studies and International Development Studies: Roskilde University. (M.A. Dissertation).

Robinson, ANDREW. 1989. Satyajit Ray: The Inner Eye. Berkeley \& Los Angeles: University of California Press. 
SARKAR, SRIJITA. 2012. An Analysis of Hindi Women-centric Films in India. Department of Sociology, University of Loiseville: USA. https://doi.org/10.18297/etd/1265 (M.A. Dissertation, under Electronic Theses and Dissertation. Paper 1265).

Schroeder, Jonathan E. 1998. Consuming Representation: A Visual Approach to Consumer Research. In Barbara B Stern (ed.), Representing Consumers: Voices, Views and Visions, 193-230. London: Routledge.

Silverman, KajA. 1988. The Acoustic Mirror: The Female Voice in Psychoanalysis and Cinema. Blomington \& Indianapolis: Indiana University Press.

Silverman, KaJA. 1992. Male Subjectivity at the Margins.

New York \& London: Routledge.

Singh, UdAYA NARAYANA. 2010. Kshayita, kshanta, kshata:

He adhunahata' (in Bengali) Sahityer Bhasha: Bhashar Sahitya 22. 280-307. Kolkata: Anushtup.

SuMMERS, DAVID. 1993. Form and Gender. New Literary History (The Johns Hopkins University Press),24(2). 243271.

WelsCH, J. R. 1987. Feminist Film Theory/Criticism in the United States. Journal of Film and Video, 39(2). 66-82.

WORLD BANK. 2001. Engendering Development: Through Gender Equality in Rights, Resources, and Voice, Washington: World Bank, Oxford University Press.

$* * *$

\section{Cite this Work:}

Maiti, Anwita \& Singh, Udaya Narayana. 2020. From Theory to Praxis: Film Theories Translated. Translation Today, Vol. 14(2). 37-62. DOI:10.46623/tt/2020.14.2.ar3 